\title{
Another Phocine Distemper Outbreak in Europe
}

\section{Trine Jensen, ${ }^{1}$ Marco van de Bildt, ${ }^{1}$ Hans Henrik Dietz, ${ }^{2}$ Ths. Holmen Andersen, ${ }^{2}$ Anne Sofie Hammer, ${ }^{2}$ Thijs Kuiken, ${ }^{3}$ Albert Osterhaus ${ }^{1,3}$}

The seal population of Northern Europe was able to recover from the 1988 phocine distemper epidemic that killed about 18,000 seals. However, starting at the beginning of May 2002, unusually high mortality among harbor seals (Phoca vitulina) was noted on the shores of Anholt, an island off the east coast of Denmark. Since then, 182 of about 900 animals, both adult and juvenile, died with clinical signs of respiratory and nervous disease. About 440 seals have been found dead on the east coast of Denmark, and the disease also appears to have spread to Sweden, where 100 seals were reported dead along the west coast (1). Most recently, over 10 seals were found moribund or dead along the coast of the Netherlands in the second half of June. The clinical signs observed were reminiscent of those in seals that died in 1988 of infection with a morbillivirus (2), subsequently identified as PDV, a new member of the genus (3).

We performed necropsies on seven seals (four adults, one subadult, and two juveniles) in variable states of decomposition found at Anholt or on the nearby Danish mainland and on one freshly dead juvenile seal from Vlieland, an island off the Dutch coast. Tissue samples (lung, kidney, bladder, and brain) were examined for morbillivirus nucleic acid by reverse-transcriptase polymerase chain reaction (RT-PCR), with a set of universal morbillivirus primers, P1 (5'-ATGTTTATGATCACAGCGGT-3') and P2 (5'-ATTGGGTTGCACCACTTGTC-3'), that are based on conserved sequences in the phosphoprotein $(\mathrm{P})$ gene. Tissue samples from three Danish seals (two adults and one juvenile) and the Dutch seal were positive, giving the expected products of 429 base pairs (bp). Selected fragments of the PCR products were sequenced for phylogenetic analysis. The resulting sequences closely matched $(>97 \%$ homology) those of PDV isolates from harbor seals in 1988 and were distinct from those of canine distemper virus (CDV) and other members of the genus Morbillivirus (Fig. 1). Except for one nucleotide change in the $\mathrm{P}$ gene fragment, the sequences obtained from Denmark and the Netherlands were identical, indicating that seals from widely separated regions of Northern Europe were infected by the same virus. Serum samples were tested for morbillivirus-specific immunoglobulin M (IgM) antibody by antibody-capture enzyme- linked immunosorbent assay (ELISA), with goat antibody to dog IgM-coated plates and peroxidase-labeled CDV antigen for detection. The goat antibody to $\operatorname{dog} \operatorname{IgM}$ preparation specifically captures seal IgM, as was shown in routine serological tests for CDV infection. Two adult Danish seals and the Dutch seal had IgM antibodies, showing re-

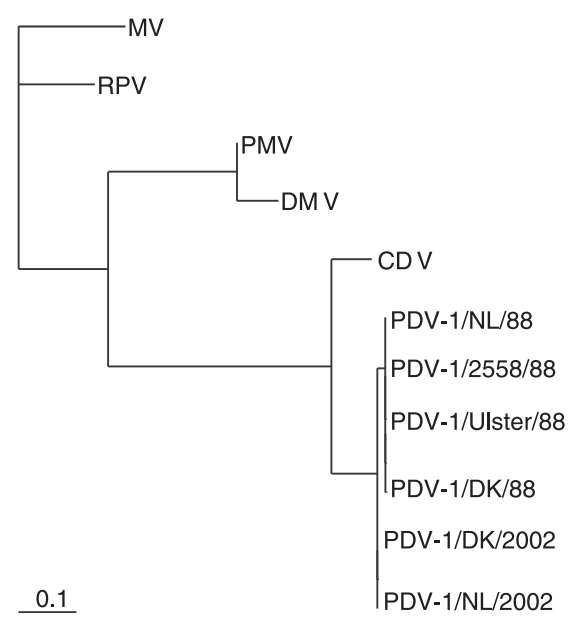

Fig. 1. Phylogenetic tree based on a 370-bp Morbillivirus $\mathrm{P}$ gene fragment. The maximum likelihood tree was generated with the SEQBOOT and DNAML program of the Phylip 3.75 software package with 100 bootstraps. When available, GenBank accession numbers are given in parentheses. MV, measles virus, Edmonston strain (M89920); RPV, rinderpest virus, RBOK strain (X68311); DMV, dolphin morbillivirus (Z47758); PMV, porpoise morbillivirus strain 53 (8); CDV, canine distemper virus, Onderstepoort strain (AF305419); PDV-1/NL/88, phocine distemper virus 1 (AF525289); PDV-1/DK/88 (X75960), PDV1/2558/88 (X65512), PDV-1/Ulster/88 (D10371), PDV-1/DK/2002 (AF525287), and PDV-1/NL/2002 (AF525288).

cent infection. These findings, together with the known severity of PDV infection in harbor seals (4), indicate that PDV infection is the cause of ongoing harbor seal mortality in Northern Europe.

In 1988, the disease spread rapidly from Anholt in April to the Wadden Sea by May, to the southern Baltic Sea by July, and to the waters around the United Kingdom by $\mathrm{Au}$ gust, killing about 18,000 animals (5). The current sequence of events parallels the early pattern of the 1988 outbreak. The rapid spread of this high-mortality disease may be explained by the migratory behavior of harbor seals, which may travel hundreds of kilometers within days. The effect of the current PDV epidemic will depend on the overall resistance and specific immunity of the Northern European seal population. The recovery of seal numbers in the Wadden Sea from about 4000 in 1989 to 17,000 in 2000 (6), indicates that, at the very most, one-fifth of the current seal population may have specific immunity to PDV resulting from the 1988 epidemic. Furthermore, for the past 10 years, we have systematically tested all Wadden Sea seals [harbor and gray (Halichoerus grypus)] admitted to the Seal Rehabilitation and Research Center in the Netherlands for serum antibodies to PDV by ELISA confirmed by VN assay. Of the 736 animals tested (95\% of whom were less than 1 year of age), over $95 \%$ were seronegative. All positive titers involved recently weaned pups, and most probably represent passive antibody derived from mothers that had survived the 1988 epidemic. Since 1997, 197 seals also were tested by virus isolation and/or RT-PCR with consistently negative results. Collectively, these data indicate that PDV has not been circulating in this population for at least 10 years, corroborating the prediction of Grenfell et al. by mathematical modeling (7) that PDV would be eliminated from the Northern European harbor seal population after 1988. The recent reappearance of PDV in this largely susceptible Northern European seal population may allow its rapid spread with devastating consequences. During the previous epidemic, thousands of seal carcasses littered beaches of the North Sea and adjacent waters. The responsible ministries and nongovernmental organizations of the respective countries involved are now discussing preparations for the possible consequences if history is repeated.

\section{References and Notes}

1. B. Reineking, Information on dead seals in the Danish and Swedish Kattegat/Skagerrak area and in the Wadden Sea in 2002 (Common Wadden Sea Secretariat, 19 June 2002). (See status report no. 9 at www.waddensea-secretariat.org/news/news/Seals/01seal-news.html\#19-06.)

2. A. D. Osterhaus, E. J. Vedder, Nature 335, 20 (1988).

3. S. L. Cosby et al., Nature 336, 115 (1988).

4. A. D. Osterhaus et al., Nature 337, 21 (1989).

5. R. Dietz, M.-P. Heide-Jørgensen, T. Härkönen, Ambio 18, 258 (1989).

6. S. Tougaard et al., Wadden Sea Newsl. (2000), p. 29.

7. B. T. Grenfell, M. E. Lonergan, J. Harwood, Sci. Total Environ. 115, 15 (1992).

8. T. Barrett et al., Virology 193, 1010 (1993).

${ }^{1}$ Seal Rehabilitation and Research Center, Hoofdstraat 94A, NL-9968 AG Pieterburen, Netherlands. ${ }^{2}$ Danish Veterinary Institute, 2 Hangovej, DK-8200 Aarhus N, Denmark. ${ }^{3}$ Erasmus MC, Institute of Virology, Dr. Molewaterplein 50, 3015 GE Rotterdam, Netherlands. 